\title{
Increasing species richness of the macrozoobenthic fauna on tidal flats of the Wadden Sea by local range expansion and invasion of exotic species
}

\author{
J. J. Beukema $\cdot$ R. Dekker
}

Received: 26 April 2010/Revised: 25 June 2010/Accepted: 29 June 2010/Published online: 18 July 2010

(C) The Author(s) 2010. This article is published with open access at Springerlink.com

\begin{abstract}
A 40-y series of consistently collected samples (15 fixed sampling sites, constant sampled area of $15 \times 0.95 \mathrm{~m}^{2}$, annual sampling only in late-winter/earlyspring seasons, and consistent sieving and sorting procedures; restriction to 50 easily recognizable species) of macrozoobenthos on Balgzand, a tidal flat area in the westernmost part of the Wadden Sea (The Netherlands), revealed significantly increasing trends of species richness. Total numbers of species annually encountered increased from $\sim 28$ to $\sim 38$. Mean species density (number of species found per sampling site) increased from $\sim 13$ to $\sim 18$ per $0.95 \mathrm{~m}^{2}$. During the 40 years of the 1970-2009 period of observation, 4 exotic species invaded the area: (in order of first appearance) Ensis directus, Marenzelleria viridis, Crassostrea gigas, and Hemigrapsus takanoi. Another 5 species recently moved to Balgzand from nearby (subtidal) locations. Together, these 9 new species on the tidal flats explained by far most of the increase in total species numbers, but accounted for only one-third of the observed increase in species density (as a consequence of the restricted distribution of most of them). Species density increased particularly by a substantial number of species that showed increasing trends in the numbers of tidal flat sites they occupied. Most of these wider-spreading species were found to suffer from cold winters. During the 40-y period of observation, winter temperatures rose by about $2^{\circ} \mathrm{C}$ and cold winters became less frequent. The mean number of cold-sensitive species found per site
\end{abstract}

Communicated by H.-D. Franke.

J. J. Beukema $(\square) \cdot$ R. Dekker

Royal Netherlands Institute for Sea Research NIOZ,

P.O. Box 59, 1790 AB Den Burg, Texel, The Netherlands

e-mail: jan.beukema@nioz.nl significantly increased by almost 2 per $0.95 \mathrm{~m}^{2}$. Among the other species (not sensitive to low winter temperatures), 6 showed a rising and 2 a declining trend in number of occupied sites, resulting in a net long-term increase in species density amounting to another gain of 1.6 per $0.95 \mathrm{~m}^{2}$. Half of the 50 studied species did not show such long-term trend, nor were invaders. Thus, each of 3 groups (local or alien invaders/winter-sensitive species/other increasing species) contributed to a roughly similar extent to the overall increase in species density.

Keywords Long-term changes - Species per unit area . Macrozoobenthos · Intertidal · Soft sediment . Introduced species $\cdot$ Temperature change

\section{Introduction}

Though there is widespread and right concern on globalwide declining biodiversity, reports of increasing species richness in specific areas have been reported as well. Such increases in species numbers in local areas can arise from introductions of invaders from distant locations (exceeding numbers of extinctions) or from changes in environmental conditions (when these changes promote more species than they do harm). Both types of causes can be directly influenced by man: invasions by increased shipping (Reise et al. 1999) and changes in habitat diversity and suitability by management (protection/restoration) and disturbance. A special class of changing environmental conditions affecting species richness is the ongoing climate change by which some species are locally promoted and others put at a disadvantage.

For invertebrates in the marine environment, few homogeneous data series of sufficient length appear to be 
available to reliably judge long-term trends in species richness and relate possible trends to underlying causes. There are several reports on successful introductions of exotic species leading to increases in species numbers, as displacement of autochthonous species appears to be a rare phenomenon (Reise et al. 1999; Wolff 2000). A warming climate generally results in poleward shifts of distribution areas, southern species increasing in abundance and northern species declining in the northern hemisphere (Sagarin et al. 1999). As species richness generally declines with increasing latitude, species gains tend to exceed species losses in areas at higher latitudes (Hawkins et al. 2009).

This study is based on a 40-y series of consistently collected quantitative data on macrozoobenthos in a vast area in the Dutch Wadden Sea. The Wadden Sea is an estuarine area of geologically young age and was seriously humanaltered for the last centuries (Lotze et al. 2005). Such areas appear to be particularly vulnerable for exotic invaders (Wolff 1999). The Wadden Sea is characterized by vast tidal mud and sand flats, which are inhabited by a fauna with high biomass and low species diversity (Beukema 1976; Beukema and Cadée 1997). Part of the species suffer from severe winters (Beukema 1979; 1990) and may profit from the warming climate (Beukema 1992). Data series reviewed by Van der Graaf et al. (2009) point to increasing species numbers in various parts of the Wadden Sea for recent decades. However, for methodological reasons, these trends should be considered with caution. Avoiding these methodological problems by a restriction to a delimited group of conspicuous species, we analyze changes in total species numbers as well as in species density (number of species per unit area) and relate these changes to some possible underlying processes, such as invader introductions, climate change and human disturbance.

\section{Methods}

Since around 1970, data on macrozoobenthos have been collected twice annually at 15 permanent (marked) sampling stations ("sites") located on Balgzand, a $50-\mathrm{km}^{2}$ tidal flat area in the westernmost part of the Wadden Sea. For this study, we used only data collected in late-winter/earlyspring, mostly in March, when numbers are at an annual minimum. Most (12) sites were 1-km long transects where 50 bottom samples of nearly $2 \mathrm{dm}^{2}$ each were taken at distance intervals of $20 \mathrm{~m}$, together $0.95 \mathrm{~m}^{2}$ per site. The 3 other sites were squares of $900 \mathrm{~m}^{2}$ where 9 samples of close to $0.1 \mathrm{~m}^{2}$ each were taken at randomly chosen places. The sites covered the entire intertidal range and nearly the full range of sediment types on Balgzand (Beukema and Cadée 1997). There was little change in these abiotic conditions during the 40 -y period of observation. Hard substrates such as dikes were not sampled, but animals attached to shells of mussels or oysters were included. The samples were sieved (1-mm square meshes) in the field and sorted alive in the laboratory. All living animals were picked out, sorted to species level as much as possible, and counted. Further details on the sampling area, the sampling stations, and the methods can be found in Beukema and Cadée (1997).

Temperature data were taken from Van Aken (2008). We used monthly means of surface water temperatures in the nearby Marsdiep tidal channel and averaged for each winter the means of December, January and February to obtain a mean winter water temperature.

\section{Sources of error}

Thin worms will be underestimated or completely missed, as a high proportion of them will pass the 1-mm sieve. Such species were completely excluded (e.g. nematodes, oligochaetes, tiny spionid polychaetes such as Pygospio sp.). Inevitably, sorting sieved samples with lots of debris (peat, empty shells) is imperfect: some small and inconspicuous specimens will at least partly be overlooked, even by experienced researchers. We standardized sorting and counting procedures as much as possible. Another problem arises in identification: some closely related species are so similar in external appearance that they cannot routinely be counted separately in macroscopic procedures. To reduce these errors, we decided to limit the present study to a list of 50 species that are sufficiently conspicuous and easily identifiable. To this end, we treated resembling species as one species, e.g. Corophium volutator and C. arenarium were recorded as $C$.sp., all barnacles as balanoids and all sea anemones as Anthozoa. The full list of taxa can be found at the bottom of Table 1 .

In fact, many more than these 50 macrozoobenthic species are present on Wadden Sea tidal flats, and some tens of them were regularly or occasionally found in our samples. Some hundreds of benthic invertebrate species have been reported from the tidal plus subtidal parts of the international Wadden Sea, most of them small-sized (Wolff and Dankers 1981; Petersen et al. 1996). By reducing a full list to 50 selected items, we are convinced that we anticipated a possible positive bias in the species-richness trend due to a growing skill in recognizing species.

\section{Results}

Long-term trends in species numbers and temperature

During the 1970-2009 period, the annual benthos samples taken showed significantly increasing numbers of 
Table 1 Summary of contributions by various groups of species to long-term (1970-2009) changes in macrozoobenthic species richness on Balgzand, expressed in (changes of) mean number of species per site $\left(n\right.$, per $\left.0.95 \mathrm{~m}^{2}\right)$

\begin{tabular}{llll}
\hline$N$ & Group & $n$ & Species \\
\hline 4 & Non-indigenous invaders & $+\sim 1.5$ (Fig. 4b) & See Fig. 5 \\
5 & Local invaders & $+\sim 0.2$ (Fig. 4b) & Crep, Gly, Lep, Ech, Oph $^{\text {a }}$ \\
10 & Winter-sensitive & $+\sim 1.8$ (Fig. 4a) & See Fig. 2 \\
6 & Upward trend & $+\sim 2.0$ (Fig. 4c) & Lit, Ner spp., Ete, Uro, Gam, Bal $^{\text {b }}$ \\
2 & Downward trend & $-\sim 0.4$ (Fig. 4c) & Mag, Scolel $^{\text {c }}$ \\
15 & No trend, common & $\sim 0$ (Fig. 4d) & d \\
8 & No trend, rare & $\sim 0$ (Fig. 4d) & \\
50 & All & $+\sim 5.1$ & \\
Total (see Fig. 1b) & +5.2 & &
\end{tabular}

$N$ is the number of species allotted to each group

${ }^{\text {a } C r e p i d u l a ~ f o r n i c a t a, ~ G l y c e r a ~ a l b a, ~ L e p i d o c h i t o n a ~ c i n e r e a, ~ E c h i n o c a r d i u m ~ c o r d a t u m, ~ O p h i u r a ~ o p h i u r a ~}$

${ }^{\mathrm{b}}$ Littorina littorea, Nereis spp. (mostly Alitta succinea), Eteone spp., Urothoe poseidonis, Gammarus locusta, Balanoids (Balanus crenatus, Semibalanus balanoides, Austrominius modestus)

c Magelona johnstoni, Scolelepis foliosa

d Macoma balthica, Mya arenaria, Mytilus edulis, Scrobicularia plana, Hydrobia ulvae, Retusa obtusa, Phyllodoce sp. (mostly Ph. mucosa), Arenicola marina, Bylgides sarsi, Heteromastus filiformis, Hediste diversicolor, Scoloplos armiger, Bathyporeia sp., Corophium sp., Anthozoa (mostly Metridium senile and Sagartia troglodytes)

e Abra alba, Petricola pholadiformis, Spisula subtruncata, Tellina (Angulus) fabula, Littorina obtusata, Pectinaria koreni, Neomysis/Praunus sp., Asterias rubens

macrozoobenthic species. Total numbers observed at $15 \times$ $0.95=14.25 \mathrm{~m}^{2}$ increased from $\sim 28$ in the early $1970 \mathrm{~s}$ to $\sim 38$ in the late 2000s (solid points in Fig. 1b). The mean rate of increase amounted to $0.21 \pm 0.04$ (mean and $1 \mathrm{SE})$ species year $^{-1}$. Likewise, the 15 -site means of species number per sampling site of $0.95 \mathrm{~m}^{2}$ increased from $\sim 12$ to $\sim 18$ (open points in Fig. 1b), at a mean rate of $0.13 \pm 0.02$ year $^{-1}$. Long-term means of species numbers amounted to $32.4 \pm 0.6$ and $15.2 \pm 0.3$ for sampled areas of 14.25 and $0.95 \mathrm{~m}^{2}$, respectively. Note that these numbers are underestimates of the true numbers of macrozoobenthic species present, because they are out of a maximal number of 50 listed species (considered as easily recognizable and not to be overlooked).

In accordance with the recent trend of rising temperatures, which is particularly strong in Dutch coastal waters and occurs in all seasons (Van Aken 2008, 2010), annual mean water temperatures rose by a mean rate of $\sim 0.05^{\circ} \mathrm{C}$ year $^{-1}$ during the 1970-2009 period of observation (Fig. 1a). Annual means increased from about 10 to almost $12^{\circ} \mathrm{C}$ (correlation with year number $r=0.63, n=39$, $P<0.0001$ ); fluctuations in winter (Dec-Jan-Feb periods) temperatures were stronger and more irregular (open points in Fig. 1a), but nevertheless winter water temperatures showed a significantly positive correlation with year number ( $r=0.36, n=39, P<0.05)$, again at a mean rate of increase of $\sim 0.05^{\circ} \mathrm{C}$ year $^{-1}$. Among the 40 winters of the period of observation, 8 were particularly cold (mean winter water temperature $<3^{\circ} \mathrm{C}$ ): $1970,1979,1982,1985$,
1986, 1987, 1996 and 1997 (see open points of Fig. 1a, c). Such severe winters appear to occur less frequently during the last than the first half of the 1970-2009 period.

Species numbers observed after severe winters were usually lower than after neighboring mild winters, compare open and solid points in Fig. 1c. The influence of winter temperature on species richness can be removed by addition or subtraction of a number of 1.7 (totals per $14.25 \mathrm{~m}^{2}$ ) or 1.0 (means per $0.95 \mathrm{~m}^{2}$ ) species (values taken from Fig. 3a) for each ${ }^{\circ} \mathrm{C}$ the water temperature of the preceding winter was lower or higher, respectively, than the longterm mean of $4.2^{\circ} \mathrm{C}$. The thus temperature-corrected values for species numbers still showed a statistically significant increasing trend in the course of the period of observation (Fig. 1d).

In early 1991, the species numbers were particularly low (crosses in Fig. 1c). In that year, not any mussel bed was present on Balgzand as a consequence of heavy fishing in the summer of 1990 (Beukema 1993; Beukema and Cadée 1996). In 1991, the number of species was not only reduced by the absence of the one species Mytilus edulis but also by the absence of species that use mussel shells as a hard substrate such as barnacles and periwinkles.

Effects of winter temperatures

Several zoobenthic species living on Wadden Sea tidal flats are sensitive to low winter temperatures, i.e. they show significantly reduced survival rates in severe winters 

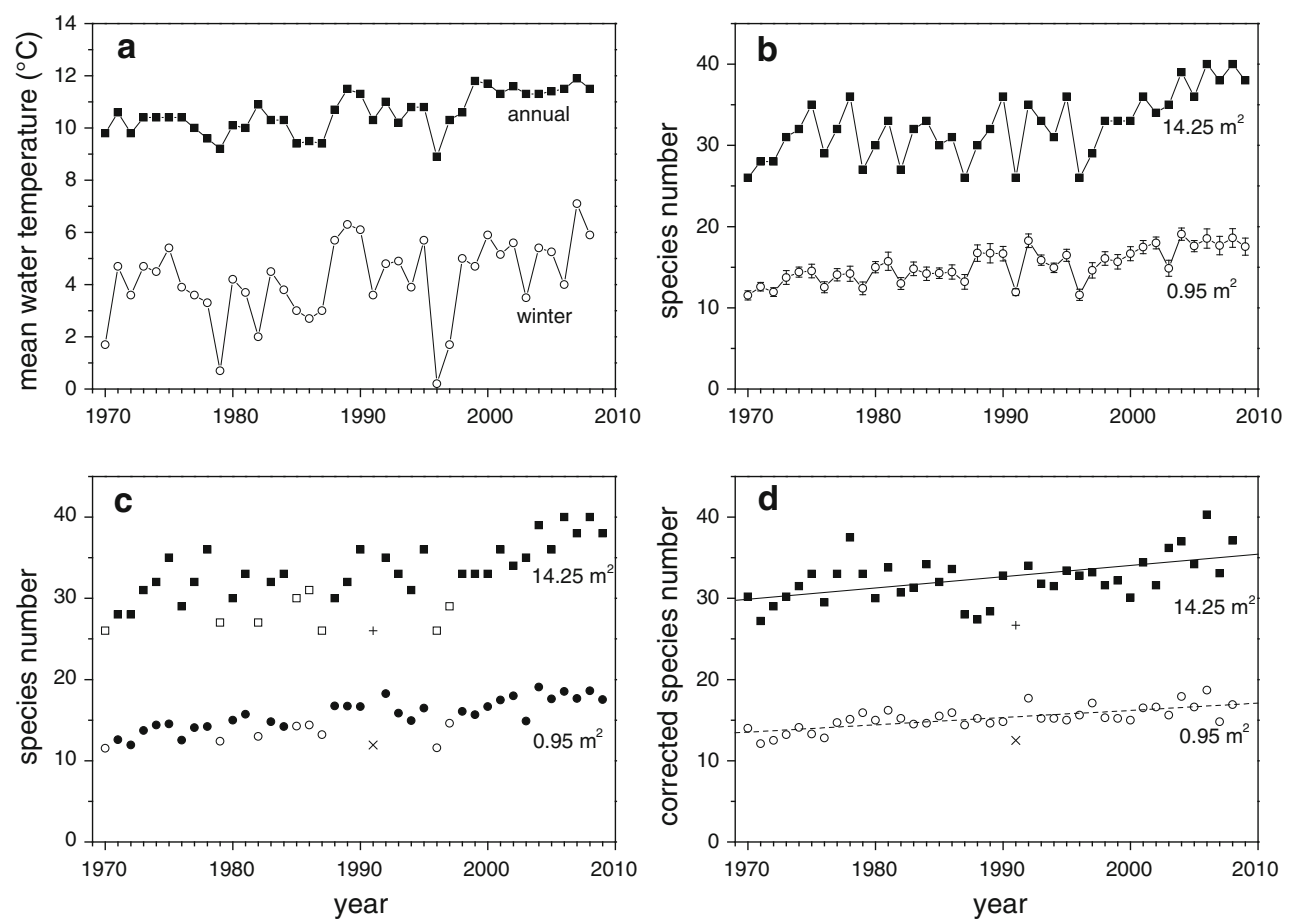

Fig. 1 Long-time (1970-2009) series of data on: a Annual means of water temperatures in the main tidal inlet of the western Wadden Sea, for (solid points) the entire year and (open points) the 3-month winter periods Dec/Jan/Feb. b Numbers $N$ of species (among a list of 50 easily recognizable macrozoobenthic species) found in late-winter/ early-spring in: (solid points) all samples together (15 sites $\times$ $0.95 \mathrm{~m}^{2}$ ) and (open points, with 1 standard error, $n=15$ ) mean number per sampling site. c Numbers as in b, but separately for samplings following a very cold winter (open points) or (solid points)

(Beukema 1979). Some of these species completely or almost completely disappear from the intertidal after the coldest winters, either at all intertidal zones (Beukema 1990) or only at the sampling sites at high intertidal levels (Beukema 1985). Beukema (1990) listed 11 of such wintersensitive species of benthic animals on Balgzand. They are all included in the present 50-species list, and 10 of them showed a significantly positive relationship between winter temperature and number of sites subsequently occupied: the bivalves Cerastoderma edule (Fig. 2d), Abra tenuis (Fig. 2b), Tellina tenuis (Fig. 2b) and Mysella bidentata (Fig. 2c), the polychaete worms Lanice conchilega (Fig. 2a) and its commensal Malmgreniella lunulata (Fig. 2a) and Nephtys hombergii (Fig. 2c), the group of Nemerteans (Fig. 2d), and the crustaceans Crangon crangon (Fig. 2e) and Carcinus maenas (Fig. 2f). The 11th species (Bylgides sarsi) that was reported to show reduced survival in cold winters did not show a significant relationship as shown in Fig. 2, nor did it show a long-term trend in numbers of site occupied.

As to be expected from the substantial share of winter-sensitive species among the macrozoobenthic fauna

a normal or mild winter. The plus and multi points refer to 1991, when the area was devoid of mussel beds. $\mathbf{d}$ Numbers as in $\mathbf{c}$, but corrected for the influence of temperature of the preceding winter (see text). Best linear fits are as follows: (b, solid points: $\left.14.25 \mathrm{~m}^{2}\right) \mathrm{N}=$ $-385+0.21$ year $(r=0.62, n=40, P<0.0001)$, (b, open points: $\left.0.95 \mathrm{~m}^{2}\right) N=-251+0.13$ year $(r=0.73, n=40, P<0.0001)$, (d, solid points, full line: $\left.14.25 \mathrm{~m}^{2}\right) N=-215+0.124$ year $(r=$ $0.50, n=38, P=0.001),\left(\mathbf{d}\right.$, open points, dashed line: $\left.0.95 \mathrm{~m}^{2}\right)$ $N=-162+0.089$ year $(r=0.72, n=38, P<0.0001)$

on Balgzand, the total numbers of species found were higher after mild than after cold winters, for both 14.25and $0.95-\mathrm{m}^{2}$ sampling areas (solid and open points of Fig. 3a). To allow for the interaction between year number and winter temperatures, the species numbers were de-trended, i.e. they were augmented by 0.21 (number per $14.25 \mathrm{~m}^{2}$ ) or 0.13 (number per $0.95 \mathrm{~m}^{2}$ ) for each year before 1990 and reduced by the same amount for each year after 1990 (correction values taken from Fig. 1b). The thus year-influence-corrected species numbers were still significantly positively correlated with preceding-winter water temperatures (Fig. 3b), increasing by $\sim 1.1\left(14.25 \mathrm{~m}^{2}\right)$ and $\sim 0.6\left(0.95 \mathrm{~m}^{2}\right)$ species per $1^{\circ} \mathrm{C}$ temperature rise.

At least 6 frequently observed species were completely absent after the coldest winters (zero points in Fig. 2 at the lowest temperatures) and some of them needed a few years after a severe winter to recover and thus remained absent for another 1 or 2 year (most of the zero points in Fig. 2 at winter temperatures of $>4^{\circ} \mathrm{C}$ ). Some other species (e.g. $N$. hombergii and C. edule, Fig. 2c, d) occurred at reduced numbers of sites after the coldest winters, but were never 

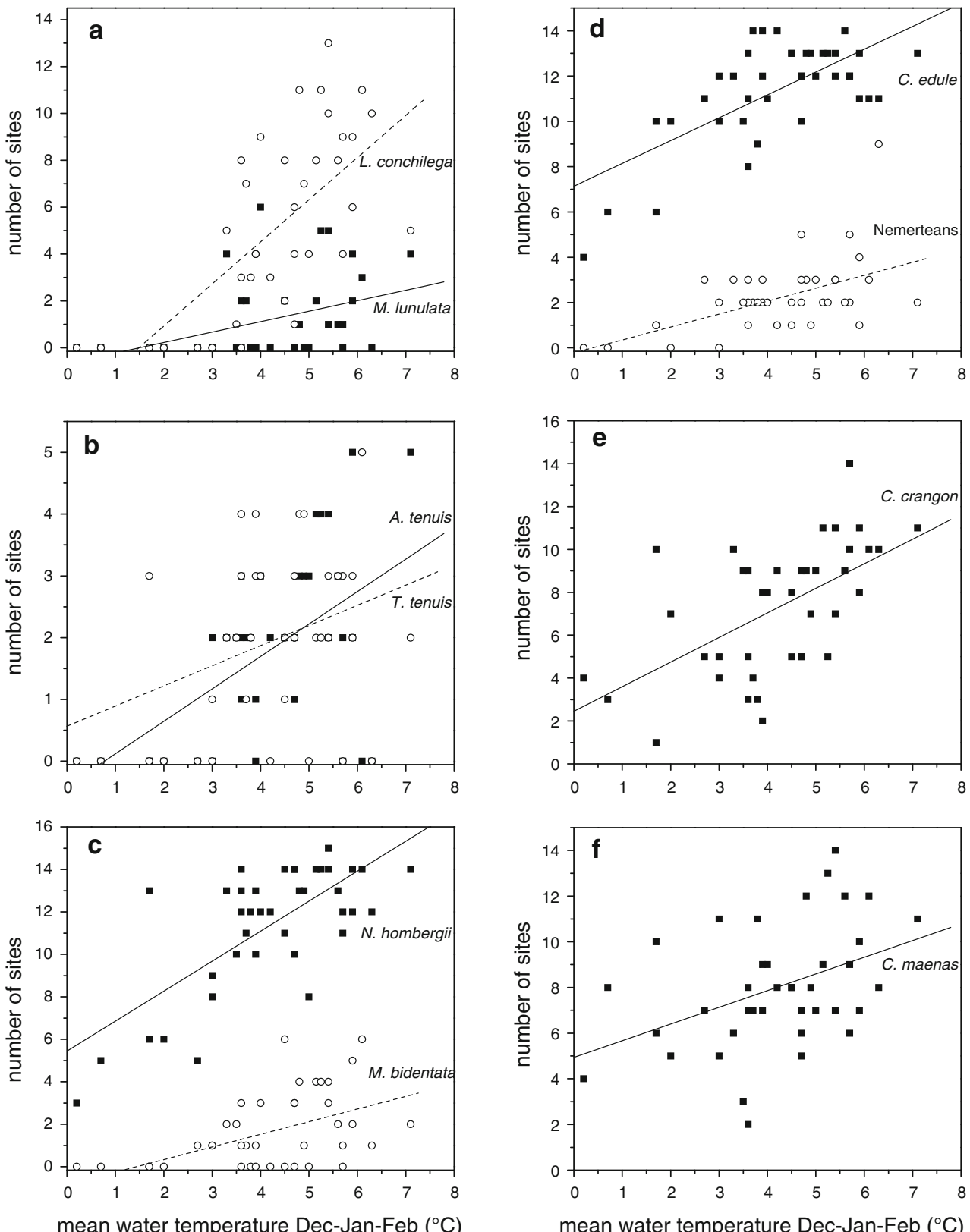

Fig. 2 Relationships between mean water temperature $\left(T\right.$ in $\left.{ }^{\circ} \mathrm{C}\right)$ in the preceding winter (temperatures as open points in Fig. 1a) and number $N$ of sampling sites (among a total of 15) where at least 1 specimen was found in the subsequent late-winter/early-spring sampling of 10 winter-sensitive species: a (open circles) Lanice conchilega, (solid squares) Malmgreniella lunulata; b (open circles) Tellina tenuis, (solid squares) Abra tenuis; c (open circles) Mysella bidentata, (solid squares) Nephtys hombergii; d (open circles) Nemertean worms, (solid squares) Cerastoderma edule; e Crangon crangon; $\mathbf{f}$ Carcinus maenas. Best linear fits: $(\mathbf{a}$, L. conchilega) $N=$ $-2.68+1.83 T(r=0.71, n=39, P<0.0001),(\mathbf{a}, M$. lunulata $)$

completely absent. Complete absence affects the total species number per $14.25 \mathrm{~m}^{2}$ as well as the mean number per $0.95 \mathrm{~m}^{2}$, whereas absence at part of the sampling sites only reduces the mean species number per $0.95 \mathrm{~m}^{2}$.

$N=-0.66+0.45 T(r=0.40, n=39, P<0.05),(\mathbf{b}, T$. tenuis $)$ $N=0.55+0.34 T(r=0.36, n=39, P<0.05),(\mathbf{b}$, A. tenuis $)$ $N=-0.41+0.53 T(r=0.55, n=39, P<0.001),(\mathbf{c}, M$. bidentata $)$ $N=-0.57+0.55 \quad T(r=0.48, \quad n=39, \quad P=0.002), \quad(\mathbf{c}, \quad N$. hombergii) $N=5.4+1.41 T(r=0.72, n=39, \quad P<0.0001)$, (d, Nemertean worms) $N=-0.2+0.58 T(r=0.54, n=39, P=$ $0.0004),(\mathbf{d}, C$. edule $) N=7.1+1.00 T(r=0.68, n=39, P<$ $0.0001),(\mathbf{e}, C$. crangon) $N=2.45+1.15 T(r=0.58, n=39$, $P=0.0001$ ), and (f, $C$. maenas) $N=4.94+0.73 T, r=0.42$, $n=39, P<0.01)$

After most of the mild winters, all of the above 10 winter-sensitive species were present at one or more sites. In these years, the group contributed a number of 10 to the total (per $14.25 \mathrm{~m}^{2}$ ) species number (solid squares in 

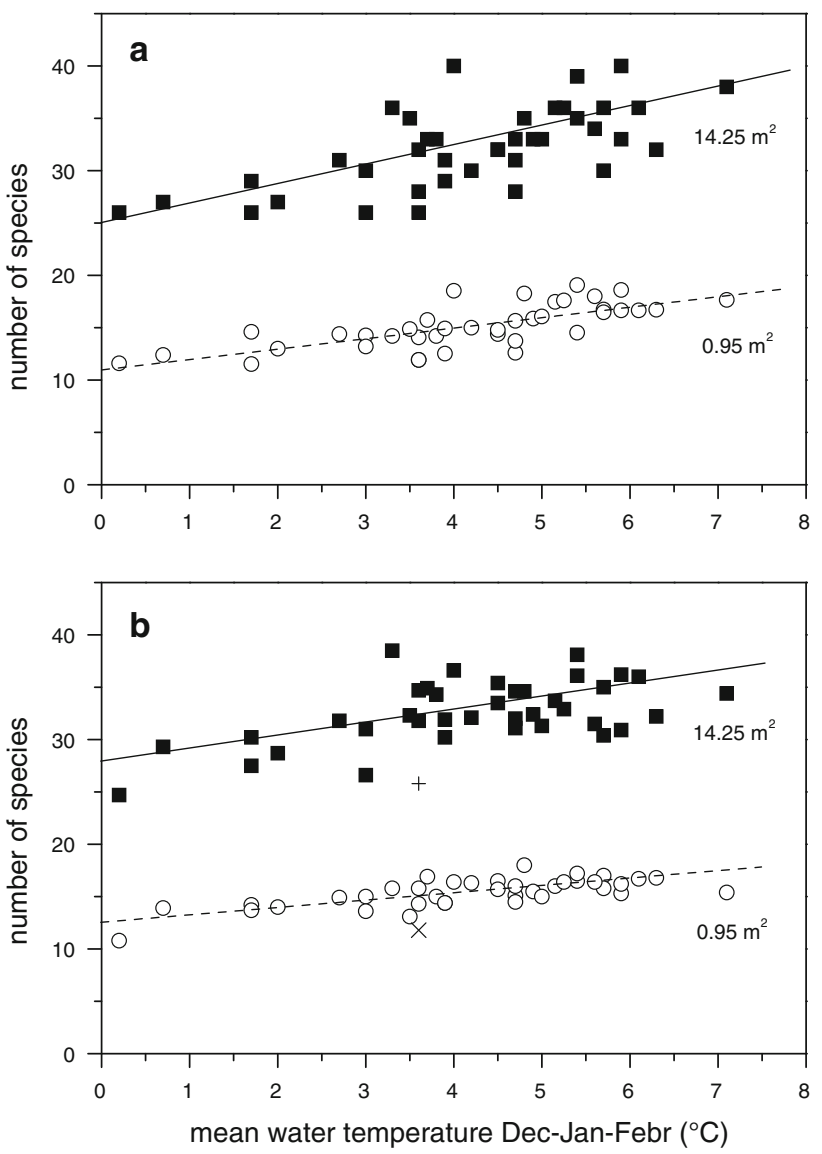

Fig. 3 Relationships between mean water temperature $\left(T\right.$ in $\left.{ }^{\circ} \mathrm{C}\right)$ in the preceding winter (as open points in Fig. 1a) and a actual numbers $N$ of species (among a list of 50 easily recognizable macrozoobenthic species) found in late-winter/early-spring in (solid points) all samples together $\left(15\right.$ sites $\left.\times 0.95 \mathrm{~m}^{2}\right)$ and (open points) mean number per sampling site $\left(0.95 \mathrm{~m}^{2}\right)$. In $\mathbf{b}$, these numbers of species have been de-trended for the influence of year number (see text). The numbers found in 1991 are indicated separately by crosses (plus for 14.25 and multi for $0.95 \mathrm{~m}^{2}$, respectively). Best linear fits: (a, full line, solid squares $) \quad N=25.1+1.70 \quad T(r=0.67, \quad n=39, \quad P<0.0001)$, (a, dashed line, open circles) $N=11.0+1.00 \quad T(r=0.72$, $n=39, P<0.0001)$, (b, full line, solid squares) $N=27.9+1.11$ $T(r=0.57, n=38, P<0.002),(\mathbf{b}$, dashed line, open circles) $N=12.7+0.63 T(r=0.71, n=38, P<0.0001)$

Fig. 1c). After cold winters, only about half of these species were present at one or more sites, resulting in a contribution of $\sim 5$ winter-sensitive species to total species numbers (open squares for 1970, 1979, 1982, 1985, 1986, 1987, 1996 and 1997 in Fig. 1c). Whenever a severe winter had occurred at least 3 years ago (as in the 1974-1978, 1991-1995, and 2000-2009 periods), the contributions of winter-sensitive species were 10 or close to 10 species (solid squares of Fig. 1c). Likewise, but less pronounced, mean contributions of winter-sensitive species per $0.95 \mathrm{~m}^{2}$ were higher after mild than after cold winters (solid and open circles in Fig. 1c) and were particularly high in years long after a severe winter.
Introduced species

In the course of the 1970-2009 period of observation, at least 4 non-native species turned up in the samples. The first to appear was the American jack-knife clam Ensis directus in 1982, about 5 year after its first find in the Wadden Sea and Europe (Beukema and Dekker 1995; Von Cosel 2009). The species was observed in the Balgzand samples in nearly all years after 1982 (solid squares in Fig. 5a). The next invader was the American spionid worm Marenzelleria viridis) in 1989, 7 and 6 year after its first records in the North Sea and Wadden Sea, respectively (Essink 1999, Essink and Dekker 2002: as M. cf. wireni, but see Sikorski and Bick 2004). It rapidly spread over the entire Balgzand area, occurring at 13-15 out of the 15 sampling sites ever since 1996 (solid squares in Fig. 5b). The third exotic invader was Crassostrea gigas, appearing in the samples in 2001, about 40 and 30 year after its first deliberate introduction from East Asia into Europe and the Wadden Sea (Wolff 2005). Since 2003, it was regularly found at 2 or 3 sites (open circles in Fig. 5b). Finally, the Asian decapod Hemigrapsus takanoi (see Asakura and Watanabe 2005) turned up in the samples in 2006, more than 20 year after its first find in Europe (Gollasch 1999). It was subsequently found every year at 1-3 sites (open circles in Fig. 5a).

Apart from the above 4 invasive species that recently arrived in Europe, 5 more species (that were already present in the North Sea area for at least decades) were only recently observed on the Balgzand tidal flats: Crepidula fornicata, Glycera alba, Lepidochitona cinerea, Echinocardium cordatum and Ophiura ophiura. This small group of newcomers on the Balgzand tidal flats was observed in small numbers (mostly only 1 specimen) at few sites (mostly only 1 site), thus contributing little to species numbers per $0.95 \mathrm{~m}^{2}$ (open points in Fig. $4 \mathrm{~b}$ ).

\section{Other species}

Among the remaining 31 species (50-10-4-5), 6 showed a statistically significant upward and 2 a significant downward trend in the numbers of sites where they were encountered in the successive years of the 1970-2009 period of observation. Together, the 6 species with a positive trend (Littorina littorea, Nereis spp. (mostly Alitta succinea, but also including some A. virens and Eunereis longissima), Eteone spp., Urothoe poseidonis, Gammarus locusta, and the group of Balanoids) showed an increase in mean numbers of species per site from $\sim 0.7$ to $\sim 2.7$ species per $0.95 \mathrm{~m}^{2}$ (Fig. 4c). The 2 species with a negative trend (Magelona johnstoni, Scolelepis foliosa) showed a decline from $\sim 0.7$ to $\sim 0.3$ species per $0.95 \mathrm{~m}^{2}$ (Fig. 4c). Thus, the net contribution to species density of 

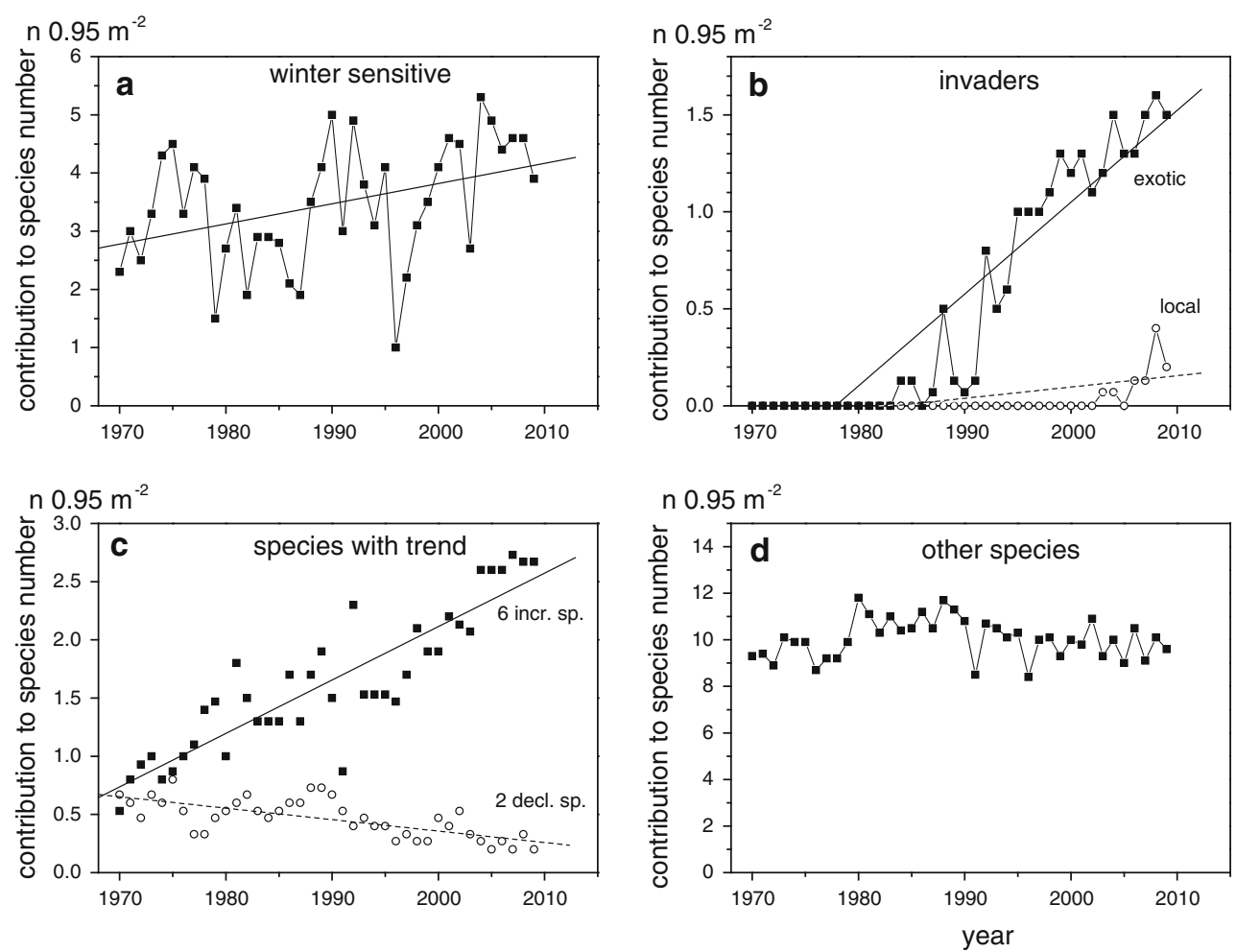

Fig. 4 Long-term (1970-2009) changes in the contributions to total species richness ( $n=$ mean number of species per $0.95 \mathrm{~m}^{2}$ ) of 4 groups of species: a the 10 species of Fig. 2 that showed a statistically significant relationship between winter temperature and number of sites where they were found, $\mathbf{b}$ two groups of invaders: (solid points) the 4 exotic species that were newly found in the Wadden Sea and (open points) 5 non-exotic species observed on Balgzand only in recent years, c (solid points) the 6 other species that showed an increasing trend and (open points) the 2 species that

the 8 species with a significant trend amounted to a positive value of $2.0-0.4=1.6$ species per $0.95 \mathrm{~m}^{2}$. The remaining 23 species did not contribute (neither positively nor negatively) to species density (Fig. 4d).

\section{Discussion}

A long period of consistent sampling of the macrozoobenthic fauna on the Balgzand tidal flats revealed a gradual increase in species richness. Expressed as total number of species encountered, the increase amounted to about $35 \%$ ( $\sim 28$ to $\sim 38$ ) over the entire 40-y period of observation. Expressed as a mean number per sampling site, the increase was of a similar magnitude $(\sim 13$ to $\sim 18$ per $0.95 \mathrm{~m}^{2}$ ). As a measure of species richness, we consider the latter estimate of species density superior to total species number, because the total number found in any year strongly depends on finds of just one individual of a rare species. Each of such finds would add about $3 \%$ to total showed a decreasing trend in number of sites occupied, $\mathbf{d}$ all other 23 species belonging to the list of 50 easily recognizable species. Best linear fits (shown as straight lines in Figure only if statistically significant $)$ a $n=-65.6+0.035 Y(r=0.39, n=40, P=0.01)$; b (solid points) $n=-93+0.047 \mathrm{Y}(r=0.92, n=40, P<0.0001)$, (open points) $n=-6.6+0.003$ y $(r=0.52, n=40, P<0.001)$; c (solid points) $n=-89.7+0.046 y(r=0.89, n=40, P<0.0001)$ (open points) $n=19.3-0.0095 Y(r=0.68, n=40, P<-0.0001)$ d $n=12.7-0.001$ y $(r=-0.02, n=40, P=0.9)$

species number, but only about $0.5 \%$ to the number per site $(1 / 15=0.07$, being $0.5 \%$ of 14.2 , the long-term mean number of species per $0.95 \mathrm{~m}^{2}$ ).

The above numbers refer to a limited group of 50 species, all easily identifiable and relatively conspicuous. This limitation was thought imperative to exclude a possibly serious influence of growing experience of the observers in sorting samples and/or recognizing rare or similar-looking species, which would lead to undeservedly increasing estimates of numbers of species found during the long period of observation.

We identified various groups of species to contribute to the increasing trend in species richness. The 10 wintersensitive species (mentioned in Fig. 2) contributed together $\sim 1.8$ species per $0.95 \mathrm{~m}^{2}$ to the increase in species density (Fig. 4a), in accordance with the increasing trend of winter temperatures and the declining frequency of occurrence of cold winters (Fig. 1a). The species belonging to this group hardly affected the total species numbers, because they were all present at one or more sites both at 

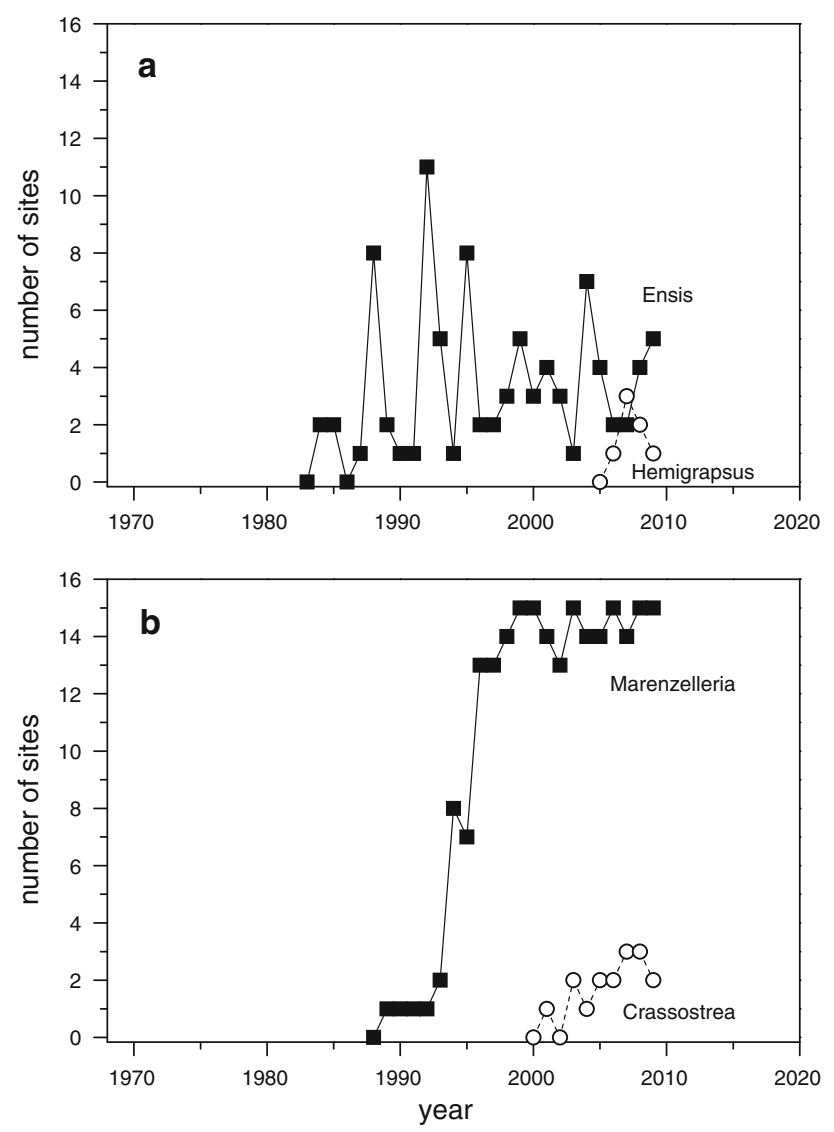

Fig. 5 Numbers of sampling sites (among a total of 15) where at least 1 specimen was found in the samples taken in late-winter/early-spring in the indicated year of 4 newly introduced species. a (solid squares) Ensis directus and (open circles) Hemigrapsus takanoi; b (solid squares) Marenzelleria viridis and (open circles) Crassostrea gigas

the start and at the end of the 40-y period. The appearance of 9 invaders, either of exotic or local origin, explained almost completely the long-term increase in total species number (amounting to 10 species). The contribution to the long-term increase in species density of exotic and local newcomers amounted to 1.5 and 0.2 species per $0.95 \mathrm{~m}^{2}$, respectively (Fig. 4b). A substantial share of the observed increase in species density was contributed by species that showed a long-term positive or negative trend in the numbers of sites occupied, but without an apparent coupling to a known change in environmental conditions. This contribution amounted to +2.0 and -0.4 (net +1.6 ) species per $0.95 \mathrm{~m}^{2}$ (Fig. 4c). Taken together, the above-mentioned groups contributed $1.8+1.7+1.6=5.1$ species per $0.95 \mathrm{~m}^{2}$, and this is close to the observed overall increase in species density of 5.2 species per $0.95 \mathrm{~m}^{2}$ (Table 1). Note that not just a few species accounted for the long-term changes in species density, but that more than half $(27 / 50)$ of the studied species were in some way involved in the explanation of this increase. On the other hand, the one 9-species group of newcomers (including
4 truly exotic species and 5 showing only local range extension) could almost completely explain the observed increase in total species number.

The observed increases in macrozoobenthic species richness may not be limited to the westernmost part of the Wadden Sea. A recent survey of the macrozoobenthos of the Wadden Sea (Van der Graaf et al. 2009) indicates increasing trends of species numbers at all 3 sites (Balgzand, Groninger Wad, Norderney) that were continuously sampled ever since the 1970s. However, as the authors rightly remark, part of these increases in species numbers will have been caused by methodological reasons (viz. the above-discussed improved species identification). In the north Frisian Wadden Sea near the island of Sylt, Reise et al. (1989) report increases in numbers of infauna species, particularly in polychaetes, between the 1930s and 1980s, resulting in enhanced numbers of species per $0.2 \mathrm{~m}^{2}$ (compare Figure 8b of Lotze 2005). Van der Graaf et al. (2009) could not confirm a suggested "polychaete takeover". In the central western North Sea, a 33-y data series by Frid et al. (2009) revealed a significant increase in numbers of genera found per $0.5 \mathrm{~m}^{2}$ from $\sim 100$ in the 1970 s to $\sim 120$ in the 1990 s and early 2000 s.

Though the trends in species richness may usually be upward, species losses have been reported from the Wadden Sea. The main causes of (local or total) species extinction in the Wadden Sea appear to be habitat change or destruction and exploitation (compare Figure 3 of Lotze et al. 2005). Several cases of habitat destruction were caused by fishery (Reise et al. 1989; Piersma et al. 2001), including disturbance of the upper bottom layer and complete removal of oyster and mussel banks. Mussel (and oyster) beds are usually richer in species than their surroundings, as these structures offer locally hard substrates to species that cannot live on the surrounding soft sediments (Buschbaum et al. 2009). The few sampling sites on Balgzand that usually included mussel beds showed higher species densities than other sites. The removal of all mussel beds in 1990 (Beukema and Cadée 1996) resulted in exceptionally low estimates of species richness at the next sampling occasion in early 1991 (see plus and multi points in Fig. 1c, d, 3b), but species richness and mussel numbers had largely recovered already by 1992 , due to highly successful reproduction in many species (including mussels) in the summer of 1991.

As in other areas, part of the increasing species richness on Balgzand was due to invaders. In Wadden Sea invertebrates, the numbers of newly introduced species exceeded those of species that became extinct (compare Figure 2 of Lotze et al. 2005). No cases appear to be known of extinction caused by an invasive species in the Wadden Sea (Wolff 2000; Lotze et al. 2005) and examples of invaders reducing abundance of other species appear to be few. An 
example of such negative interaction may be the local declines of biomass of Nereis spec. and other species simultaneously with the rapid increase in biomass of Marenzelleria viridis after their introduction (Essink et al. 1998; Essink and Dekker 2002). Markert et al. (2010) and Troost (2010) found no indication of a suppression of indigenous species by the recent establishment of reefs of Pacific oysters Crassostrea gigas in the German and Dutch Wadden Sea, respectively.

A substantial part of the observed increase in species density could be attributed to the warming climate: the 10 winter-sensitive species (Fig. 2) became more abundant and were found at an increasing number of sampling sites (Table 1; Fig. 4a). Declines in numbers of occupied sites were observed in a few species, but these declines appeared to be unrelated to temperature change. A few species, notably the bivalve Macoma balthica do suffer from the warming climate and showed declining trends in abundance for recent decades (Beukema et al. 2009). So far, however, this did not result in declining numbers of sites were they were found. Thus, the longterm warming trends resulted in increasing species richness on the Balgzand tidal flats. This conclusion is in accordance with that of Hawkins et al. (2009) for British rocky-shore fauna, that more southern (warm-water) species have been recorded advancing than northern (cold-water) species retreating. A similar conclusion was reached by Sagarin et al. (1999) for the Californian rocky intertidal.

The two processes (invasions and advancement of species, mostly by climate change) that caused the increase in species richness on Balgzand tidal flats are still in progress and may be expected to continue. Immigration of alien species by a.o. transport in ballast water, attachment to ship hulls or to imported organisms (such as oysters) cannot completely be prevented. Brackish estuaries and other coastal areas appear to offer plenty of open niches for newcomers (Wolff 1999; Reise et al. 1999). Further spread of lower-latitude species into a poleward direction (in fact largely a re-colonization process ever since the Ice Ages) will rapidly continue as long as global warming continues. So far, there are no signs of extirpation of species in the study area as a consequence of warming. Warming promoted the distribution of winter-sensitive species that were already present in the area. Occasional cold winters caused an immediate but temporary reduction in species number and species density, but recovery went rapidly. In conclusion, we expect further increases in species numbers and species-density values from all processes underlying the observed increase in species richness.

Acknowledgments This study is part of a long-term monitoring program on macrozoobenthos in the Wadden Sea executed by NIOZ and financially supported by the Dutch Ministry of Transport, Public Works and Water Management, Water Service (RWS-Waterdienst).

Open Access This article is distributed under the terms of the Creative Commons Attribution Noncommercial License which permits any noncommercial use, distribution, and reproduction in any medium, provided the original author(s) and source are credited.

\section{References}

Asakura A, Watanabe S (2005) Hemigrapsus takanoi, new species, a sibling species of the common Japanese intertidal crab H. penicillatus (Decapoda: Brachyura: Grapsoidea). J Crust Biol 25:279-292

Beukema JJ (1976) Biomass and species richness of the macrobenthic animals living on the tidal flats of the Dutch Wadden Sea. Neth J Sea Res 10:236-261

Beukema JJ (1979) Biomass and species richness of the macrobenthic animals living on a tidal flat area in the Dutch Wadden Sea: effects of a severe winter. Neth J Sea Res 13:203-223

Beukema JJ (1985) Zoobenthos survival during severe winters on high and low tidal flats in the Dutch Wadden Sea. In: Gray JS, Christiansen ME (eds) Marine biology of polar regions and effects of stress on marine organisms. Wiley, Chichester, pp 351-361

Beukema JJ (1990) Expected effects of changes in winter temperatures on benthic animals living in soft sediments in coastal North Sea areas. In: Beukema JJ, Wolff WJ, Brouns JJWM (eds) Expected effects of climatic change on marine coastal ecosystems. Kluwer, Dordrecht, pp 83-92

Beukema JJ (1992) Expected changes in the Wadden Sea benthos in a warmer world: lessons from periods with mild winters. Neth $\mathbf{J}$ Sea Res 30:73-79

Beukema JJ (1993) Increased mortality in alternative bivalve prey during a period when the tidal flats of the Dutch Wadden Sea were devoid of mussels. Neth J Sea Res 31:395-406

Beukema JJ, Cadée GC (1996) Consequences of the sudden removal of nearly all mussels and cockles from the Dutch Wadden Sea. PSZN: Mar Ecol 17:279-289

Beukema JJ, Cadée GC (1997) Local differences on macrozoobenthic response to enhanced food supply caused by mild eutrophication in a Wadden Sea area: food is only locally a limiting factor. Limnol Oceanogr 42:1424-1435

Beukema JJ, Dekker R (1995) Dynamics and growth of a recent invader into European coastal waters: the American razor clam, Ensis directus. J Mar Biol Ass UK 75:351-362

Beukema JJ, Dekker R, Jansen JM (2009) Some like it cold: populations of the tellinid bivalve Macoma balthica $(\mathrm{L}$.) suffer in various ways from a warming climate. Mar Ecol Prog Ser 384:135-145

Buschbaum C et al (2009) Mytilid mussels: global habitat engineers in coastal sediments. Helgol Mar Res 63:47-58

Essink K (1999) Dispersal and development of Marenzelleria spp. (Polychaeta, Spionidae) populations in NW Europe and The Netherlands. Helgol Meeresunters 52:367-372

Essink K, Dekker R (2002) General patterns in invasive ecology tested in the Dutch Wadden Sea: the case of a brackish-marine polychaetous worm. Biol Invasions 4:359-368

Essink K, Eppinga J, Dekker R (1998) Long-term changes (1977-1994) in intertidal macozoobenthos of the Dollard (Ems estuary) and effects of introduction of the North American spionid polychaete Marenzelleria cf. wireni. Senckenb Marit 28:211-225 
Frid CLJ, Garwood PR, Robinson LA (2009) Observing change in a North Sea benthic system: a 33 year time series. J Mar Syst 77:227-236

Gollasch S (1999) The Asian decapod Hemigrapsus penicillatus (De Haan, 1835) (Grapsidae, Decapoda) introduced in European waters: status quo and future perspective. Helgol Meeresunters 52:359-366

Hawkins SJ et al (2009) Consequences of climate-driven biodiversity changes for ecosystems functioning of North European rocky shores. Mar Ecol Prog Ser 396:245-259

Lotze HK (2005) Radical changes in the Wadden Sea fauna and flora over the last 2,000 years. Helgol Mar Res 59:71-83

Lotze HK et al (2005) Human transformations of the Wadden Sea ecosystem through time: a synthesis. Helgol Mar Res 59:84-95

Markert A, Wehrmann A, Kröncke I (2010) Recently established Crassostrea-reefs versus native Mytilus-beds: differences in ecosystem engineering affects the macrofaunal communities (Wadden Sea of Lower Saxony, southern German Bight). Biol Invasions 12:15-32

Petersen et al. (1996) Red list of macrofaunal benthic invertebrates of the Wadden Sea. Helgol Meeresunters 50(suppl.):69-76

Piersma T, Koolhaas A, Dekinga A, Beukema JJ, Dekker R, Essink K (2001) Long-term indirect effects of mechanical cockle-dredging on intertidal bivalve stocks in the Wadden Sea. J Appl Ecol 38:976-990

Reise K, Herre E, Sturm M (1989) Historical changes in the benthos of the Wadden Sea around the island of Sylt in the North Sea. Helgol Meeresunters 43:417-433

Reise K, Gollasch S, Wolff WJ (1999) Introduced marine species of the North Sea coasts. Helgol Meeresunters 52:219-234
Sagarin RD, Barry JP, Gilman SE, Baxter CH (1999) Climate-related change in an intertidal community over short and long time scales. Ecol Monogr 69:465-490

Sikorski AV, Bick A (2004) Revision of Marenzelleria Mesnil, 1896 (Spionidae, Polychaeta). Sarsia 89:253-275

Troost K (2010) Causes and effects of a highly successful marine invasion: case-study of the introduced Pacific oyster Crassostrea gigas in continental NW European estuaries. J Sea Res (in press)

Van Aken HM (2008) Variability of the water temperature in the western Wadden Sea on tidal to centennial scales. J Sea Res 60:227-234

Van Aken HM (2010) Meteorological forcing of long-term temperature variations of the Dutch coastal waters. J Sea Res 63:143-151

Van der Graaf S, De Vlas J, Herlyn M, Voss J, Heyer K, Drent J (2009) Macrozoobenthos. Thematic report no. 10. In: Marencic H, De Vlas J (eds) Quality status report 2009. Wadden Sea Ecosystems No. 25. Common Wadden Sea Secretariat, Wilhelmshaven

Von Cosel R (2009) The razor shells of the eastern Atlantic, part 2. Pharidae II: the genus Ensis Schumacher, 1817 (Bivalvia, Solenoidea). Basteria 73:9-56

Wolff WJ (1999) Exotic invaders of the meso-oligohaline zone of estuaries in the Netherlands: why are there so many? Helgol Meeresunters 52:393-400

Wolff WJ (2000) Causes of extirpation in the Wadden Sea, an estuarine area in the Netherlands. Conserv Biol 14:876-885

Wolff WJ (2005) Non-indigenous marine and estuarine species in The Netherlands. Zool Meded Leiden 79(1):1-116

Wolff WJ, Dankers N (1981) Preliminary checklist of the zoobenthos and nekton species of the Wadden Sea. In: Wolff WJ (ed) Ecology of the Wadden Sea Balkema, Rotterdam 1(4):24-60 